\title{
Adaptability and Stability of Yield and Industrial Grain Quality with and without Fungicide in Brazilian Oat Cultivars
}

\author{
José Antonio Gonzalez da Silva1, Maisa Didoné Wohlenberg1, Emilio Ghisleni Arenhardt², \\ Antonio Costa de Oliveira ${ }^{3}$, Gustavo Mazurkievicz ${ }^{2}$, Mariele Müller ${ }^{4}$, \\ Lorenzo Ghisleni Arenhardt', Manuel Osorio Binelo ${ }^{5}$, Guilherme Arnold', Rafael Pretto ${ }^{1}$ \\ ${ }^{1}$ Department of Agrarian Studies, Regional University of the Northwest of Rio Grande do Sul, ljuí, Brazil \\ ${ }^{2}$ Department of Crop Plants, Federal University of Rio Grande do Sul, Porto Alegre, Brazil \\ ${ }^{3}$ Faculty of Agronomy EliseuMaciel, Federal University of Pelotas, Pelotas, Brazil \\ ${ }^{4}$ Faculty of Agronomy, University of Passo Fundo, Passo Fundo, Brazil \\ ${ }^{5}$ Department of Exact Sciences and Engineering, Regional University of the Northwest of Rio Grande do Sul, \\ ljuí, Brazil \\ Email: emilio.arenhardt@yahoo.com.br
}

Received 19 May 2015; accepted 22 June 2015; published 25 June 2015

Copyright (C) 2015 by authors and Scientific Research Publishing Inc.

This work is licensed under the Creative Commons Attribution International License (CC BY). http://creativecommons.org/licenses/by/4.0/

c) (i) Open Access

\section{Abstract}

The use of productive cultivars with adaptability and stability and less demanding to fungicide use are critical to the sustainability of production factors. The objective of this work was to determine the per se performance of white oat cultivars and parameters of adaptability and stability on yield and grain quality in the proposition of cultivars more responsive in reducing the use fungicide. The study was conducted in Augusto Pestana, RS, Brazil, between the years 2010 and 2013. The experimental design was randomized blocks with six replicates, three with and three without fungicide. The study evaluated 14 white oat cultivars for yield and industrial capability. The white oat cultivars FAEM 4 Carlasul and URS Corona indicate high grain yield with stability and general adaptability, independent of chemical control. The cultivar URS Corona shows together high yield and thousand grain weight and hectoliter with general adaptability and stability in the absence of fungicide. Although no stability has been detected in industrial yield without the use of fungicides, cultivars of URS Charrua, URS Corona and URS Taura show high means with general adaptability.

\section{Keywords}

Avena sativa L., Grain Quality, Fungicide, Climatic Variations

How to cite this paper: da Silva, J.A.G., Wohlenberg, M.D., Arenhardt, E.G., de Oliveira, A.C., Mazurkievicz, G., Müller, M., Arenhardt, L.G., Binelo, M.O., Arnold, G. and Pretto, R. (2015) Adaptability and Stability of Yield and Industrial Grain Quality with and without Fungicide in Brazilian Oat Cultivars. American Journal of Plant Sciences, 6, 1560-1569. 


\section{Introduction}

The white oat (Avena sativa L.) is a species of cool season multipurpose. It's used in succession and rotation of crops breaking the cycle of pests and diseases and excellent ground cover to the till system [1] [2], and in addition, to the animals providing feed, hay, silage and forage of quality [2] [3]. For human consumption, the grains stand out as a functional food rich in protein and fiber. Among these, the dietary fiber beta glucan assists in lowering cholesterol LDL [4] [5].

The inclusion of oats in the diet has grown tremendously in recent years due to more demanding population and seeking more nutritious and healthy foods [6] [7]. On the other hand, oat consumption is based product "in natura" that after peeling is directed production bran, flour or flakes, implying greater care in the production process, especially in the use of agrochemicals to control fungal diseases.

The pattern of targeted oat requires high grain yield cultivars with technological standards desired by industry. Therefore, the high percentage of caryopsis, the high weight of hectoliter and the grain size have been increasingly required [6]-[8]. These characteristics are not always obtained due to climatic factors and the prevalence of fungal diseases [9] [10]. Among the diseases, leaf rust (Puccinia coronata C da. f. sp. avenae) and helminthosporiosis [Drechslera avenae (Eidam) El Sharif] have received special attention [11] [12].

Reference [13] reported that diseases are not satisfactorily controlled by resistant cultivars, because the resistance level is not long lasting and sufficient to reduce the damage. Thus, besides genetic resistance, the use of fungicides show the fastest and most efficient measure in disease control, improving the yield and grain quality [12]-[14]. These conditions justify an unsustainable model of agriculture, because of increasing production costs and the contamination of the products [12]-[15].

Sensitivity to environmental conditions and susceptibility to foliar diseases may be associated with large variability of edaphoclimatic conditions in Brazil and the indication of cultivars of reduced adaptability and stability to different microclimates [16] [17]. In modern agriculture, the recommendation of cultivars with high grain yield and with stability to climatic variations is decisive, by taking advantage of improved environments or that showing adequate performance under adverse conditions [6]-[18]. Like this, the identification of genotypes of oats of high performance in characters of agronomic interest and industry, less demanding the use of fungicide and with adaptability and stability, may favor a more sustainable production of oat cultivation.

The objective of this work was to determine the per se performance of white oat cultivars and parameters of adaptability and stability on yield and grain quality in the proposition of cultivars more responsive in reducing the use fungicide.

\section{Materials and Methods}

The work was developed between the years 2010 to 2013 in the municipality of Augusto Pestana, RS, Brazil ( $28^{\circ} 26^{\prime} 30^{\prime \prime}$ South latitude and $54^{\circ} 00^{\prime} 58^{\prime \prime}$ West longitude). The soil of the area is classified as Oxisol Distroferric Typical and the climate, according to Köppen classification, is Cfa, with hot summer without a dry season. In the study, ten days before the sowing, was performed soil analysis and identified the following chemical characteristics of the local: $\mathrm{pH}=6.2 ; \mathrm{P}=33.9 \mathrm{mg} \cdot \mathrm{dm}^{-3} ; \mathrm{K}=200 \mathrm{mg} \cdot \mathrm{dm}^{-3}$, Organic Matter $=3.4 \% ; \mathrm{Al}=0.0$ $\mathrm{cmol}_{\mathrm{c}} \cdot \mathrm{dm}^{-3} ; \mathrm{Ca}=6.5 \mathrm{cmol}_{\mathrm{c}} \cdot \mathrm{dm}^{-3}$ and $\mathrm{Mg}=2.5 \mathrm{cmol}_{\mathrm{C}} \cdot \mathrm{dm}^{-3}$. The sowings were performed in the second fortnight of May with seeder-fertilizer, where each parcel was formed of 5 lines of $5 \mathrm{~m}$ in length and line spacing of 0.20 $\mathrm{m}$ to compose the experimental unit of $5 \mathrm{~m}^{2}$. The density population used was determined in accordance with the technical indications of the culture, being of 300 viable seeds per square meter. In the experiments was applied at seeding 10, 60 and $50 \mathrm{~kg} \cdot \mathrm{ha}^{-1}$ of NPK, on the basis of the levels of these elements in the soil for grain yield expectation of $3 \mathrm{t}^{\mathrm{t}} \mathrm{ha}^{-1}$. The remaining nitrogen to the desired income expectancy was applied in coverage when the plants were in the stadium of fourth leaf visible.

The experiments were conducted in experimental design of randomized blocks with six repetitions, being three without fungicide and three with fungicide for the control the leaf rust and leaf spot. In condition with fungicide, three applications were made: at the end of the stretching, in flowering and in grain filling. These conditions represent the most common application of fungicides in crops of oats of Brazil. It was used fungicide of

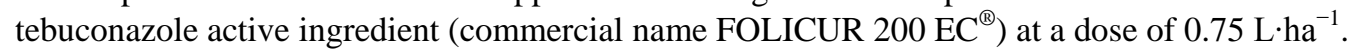

In the study were evaluated the 14 major white oat cultivars recommended for growing in Brazil, being they: Barbarasul, Brisasul, FAEM 4 Carlasul, FAEM 5 Chiarasul, URS 21, URS Guapa, URS Tarimba, URS Taura, URS Guria, URS Charrua, URS Torena, URS Corona, IAC 7 and UPFA Gaudéria. These cultivars have high 
grain yield with good quality industrial, besides the traits presented in Table 1 . Were analyzed the following characters of agronomic interest and industry: 1$)$ Grain yield $\left(\mathrm{GY}, \mathrm{kg} \cdot \mathrm{ha}^{-1}\right)$ : estimated from the grain mass from the harvest of the three central rows of each plot; 2) Thousand grain weight: (TGW, g): by the count of 250 grain and weighing in balance of accuracy and multiplied by four; 3) Weight of hectoliter $\left(\mathrm{WH}, \mathrm{kg} \cdot \mathrm{hL}^{-1}\right)$ : estimated by the ratio of grain weight on a volume of known cube $250 \mathrm{~cm}^{-3}$; 4) Number of Grains bigger than $2 \mathrm{~mm}$ (Grains $>2 \mathrm{~mm}, \mathrm{n}$ ): a sample of 100 grains were placed on a sieve with a mesh of $2 \mathrm{~mm}$ for the analysis of major and minor grains which this dimension; 5) Grain weight (GW, g): obtained by weighing 50 grains that were above $2 \mathrm{~mm}$ sieve; 6) Weight of caryopsis (WC, g): removal of the bark of 50 grains larger than $2 \mathrm{~mm}$ and weighing of caryopses; 7) Husking index (HI, $\mathrm{g}^{-1}{ }^{-1}$ ): relationship obtained between the weight of caryopses and grain weight of 50 grains of a thickness greater than $2 \mathrm{~mm}(\mathrm{HI}=\mathrm{WC} / \mathrm{WG}) ; 8)$ Industrial grain yield (IGY, $\left.\mathrm{kg} \cdot \mathrm{ha}^{-1}\right)$ : is the product obtained from the grain yield, number of grains bigger than $2 \mathrm{~mm}$ and the husking index $(\mathrm{IGY}=\mathrm{GY} \times$ Grain $>2 \mathrm{~mm} \times \mathrm{HI})$.

To meet the assumptions of homogeneity and normality via Bartlett and Lilliefors tests, the data were submitted to variance analysis for detection of main effects and interaction of the sources of variation genotype and year in the presence and absence of fungicide. The comparison of means was performed by clustering method by [19]:

$$
\lambda=\frac{\pi B_{0}}{2(\pi-2) \hat{\sigma}_{0}^{2}}
$$

where:

$B_{0}=$ maximum value of the sum of squares between groups;

$\hat{\sigma}_{0}^{2}=$ variance obtained through.

$$
\hat{\sigma}_{0}^{2}=\frac{1}{g+v}\left[\sum_{i=1}^{g}\left(\bar{Y}_{i}-\bar{Y}\right)^{2}+v s_{\bar{y}}^{2}\right]
$$

where:

\begin{tabular}{|c|c|c|c|c|}
\hline \multirow{2}{*}{ Genotype } & \multicolumn{4}{|c|}{ Main traits } \\
\hline & Cycle & Stature & Lodging & Leaf rust \\
\hline Barbarasul & Early & Short & MR & MS \\
\hline Brisasul & Medium & Short & MR & MR \\
\hline FAEM 4 Carlasul & Medium & Medium & MR & MR \\
\hline FAEM 5 Chiarasul & Medium & Medium & MR & MR \\
\hline IAC 7 & Early & High & - & $S$ \\
\hline UPFA Gaudéria & Medium & High & MS & MS \\
\hline URS 21 & Early & High & S & MR \\
\hline URS Charrua & Early & very High & MS & $\mathrm{R}$ \\
\hline URS Corona & Medium & High & MS & $\mathrm{R}$ \\
\hline URS Guapa & Early & Medium & MS & $S$ \\
\hline URS Guria & Early & High & S & S \\
\hline URS Tarimba & Early & Medium & MS & MS \\
\hline URS Taura & Early & Short & $\mathrm{R}$ & S \\
\hline URS Torena & Medium & Medium & S & MS \\
\hline
\end{tabular}

Table 1. Main agronomic traits of the oat cultivars present in study.

$\mathrm{MR}$ = moderately resistant; $\mathrm{MS}$ = moderately susceptible; $\mathrm{R}$ = resistant; $\mathrm{S}$ = susceptible. 
$\bar{Y}_{i}=$ the average treatment " $i$ " $(i=1,2, \cdots, g)$;

$\bar{Y}=$ overall average of treatments to be separated;

$g=$ number of averages to be separated;

$v=$ number of degrees of freedom of the residue;

$s_{\bar{y}}^{2}=\frac{Q M R}{r}$, being $Q M R=$ mean square of the residue and " $r$ " the number of observations.

The decision rule to establish groups:

If $\lambda<\chi_{(\alpha, v o)}^{2}$, the averages are homogeneous;

If $\lambda \geq \chi_{(\alpha, v o)}^{2}$, medium groups differ significantly.

The estimation of the parameters of adaptability and stability by [20]. Based on linear regression, the regression coefficients of phenotypic values of each genotype were estimated from an environmental index, generating estimates of parameters of adaptability and stability by the equation:

$$
Y_{i j}=\beta_{o i}+\beta_{1 i} I_{j}+\delta_{i j}+\bar{\varepsilon}_{i j}
$$

where:

$Y_{i j}$ is the means of genotype $i$ at environment $j$;

$\beta_{o i}$ : overall means genotype $i$;

$\beta_{1 i}$ : linear regression coefficient which measures the response of the genotype to variation of the environment;

$I_{j}$ : environmental index coded $\left(\sum_{j} I_{j}=0\right)$;

$\delta_{i j}$ : deviations from regression;

$\bar{\varepsilon}_{i j}$ : means experimental error.

A cultivar is stable when $\delta_{i j}=0$ and unstable when $\delta_{i j} \neq 0$. According to this methodology, adaptability is the ability of genotypes in certain condition take advantage of advantageously the environmental stimulus. For a cultivar highlight wide adaptability, it follows that $\beta_{1 i}=1$; and adapted to favorable environments when $\beta_{1 i}>1$; and adapted to unfavorable environments when $\beta_{1 i}<1$. Adaptability and stability of genotypes was measured by parameters general means, linear regression coefficient and deviations from the regression. The hypothesis that regression coefficient does not differ from one was evaluated by the test $t$, and the hypothesis that the deviations from regression of each cultivar does not differ from zero was analyzed by the test $F$. All analyses were carried out with the aid of computational GENES program.

\section{Results and Discussion}

In Table 2, the summary of the analysis of variance shows genetic differences among the oat cultivars and the presence of interaction genotype $\mathrm{x}$ year on characters of agronomic interest and industrial quality, regardless of the condition with or without chemical control. The values of mean square for the year of cultivation were superior in the scenario with and without fungicide in the expression of grain yield, weight of hectoliter and industrial yield, signaling greater contribution of amendment.

The thousand grain weight in the absence of fungicide conditioned to a greater participation of genotypic effects, indicating effective genetic differences the possibility of identification of cultivars more responsive the reduction of chemical control. The means values observed in the different scenarios show that in the presence of fungicide, general means of the variables analyzed were superior, indicating the strong action of foliar diseases on productivity and industrial quality of oat grains in the absence of fungicide (Table 2).

Studying the culture of white oats, researchers have been observing effects pronounced of genotype $\mathrm{x}$ environment interaction, concluding that the year of cultivation is the principal factor contributing to the instability of production [6] [21] [22]. Therefore, in addition to the performance per se, the understanding of the effects of the interaction genotype versus environment becomes necessary [6]-[23]. An efficient analysis in describing this interaction requires more adjusted models in defining cultivars for recommendation [5]-[24]. The analysis of adaptability and stability detail the effects of this interaction enabling define predictable and responsive behavior cultivars to environmental variations [6]-[17].

In Table 3, adaptability and stability, means values $\left(\beta_{0 i}\right)$ expressive in grain yield without fungicide were 
Table 2. Summary of the analysis of variance for oat cultivars in different years of cultivation with and without fungicide application.

\begin{tabular}{|c|c|c|c|c|c|}
\hline \multirow{3}{*}{ Source of variation } & \multirow{3}{*}{$\mathrm{DF}$} & \multicolumn{4}{|c|}{ Mean Square/without Fungicide } \\
\hline & & GY & TGW & WH & IGY \\
\hline & & $\left(\mathrm{kg} \cdot \mathrm{ha}^{-1}\right)$ & (g) & $\left(\mathrm{kg} \cdot \mathrm{hL}^{-1}\right)$ & $\left(\mathrm{kg} \cdot \mathrm{ha}^{-1}\right)$ \\
\hline Block & 2 & $343,621^{*}$ & 14.81 & 24.11 & $144,180^{*}$ \\
\hline Genotype (G) & 13 & $1,520,636^{*}$ & $76.33^{*}$ & $39.43^{*}$ & $615,963^{*}$ \\
\hline Year (Y) & 3 & $13,482,567^{*}$ & 5.93 & $1424.26^{*}$ & $3,704,306^{*}$ \\
\hline$G \times Y$ & 39 & $326,740^{*}$ & $18.36^{*}$ & $19.12^{*}$ & $174,971^{*}$ \\
\hline Error & 110 & 89,700 & 4.75 & 4.11 & 28,956 \\
\hline Total & 167 & - & - & - & - \\
\hline Mean & - & 2364 & 30.23 & 43.91 & 839 \\
\hline \multirow[t]{2}{*}{ CV (\%) } & - & 12.66 & 7.21 & 4.61 & 20.27 \\
\hline & & \multicolumn{4}{|c|}{ Mean Square/with Fungicide } \\
\hline \multirow[t]{2}{*}{ Source of variation } & \multirow[t]{2}{*}{ DF } & GY & TGW & WH & IGY \\
\hline & & $\left(\mathrm{kg} \mathrm{ha}^{-1}\right)$ & (g) & $\left(\mathrm{kg} \mathrm{hL}^{-1}\right)$ & $\left(\mathrm{kg} \mathrm{ha}^{-1}\right)$ \\
\hline Block & 2 & 320,892 & 0.10 & 12.61 & 152,493 \\
\hline Genotype (G) & 13 & $1,404,390^{*}$ & $100.71^{*}$ & $22.83^{*}$ & $937,241^{*}$ \\
\hline Year (Y) & 3 & $21,900,706^{*}$ & $160.05^{*}$ & $1184.51^{*}$ & $12,285,703^{*}$ \\
\hline $\mathrm{G} \times \mathrm{Y}$ & 39 & $280,843^{*}$ & $11.78^{*}$ & $10.61^{*}$ & $161,292^{*}$ \\
\hline Error & 110 & 103,034 & 3.83 & 6.04 & 44,210 \\
\hline Total & 167 & - & - & - & - \\
\hline Mean & - & 3111 & 33.23 & 47.64 & 1351 \\
\hline CV (\%) & - & 10.31 & 5.89 & 5.15 & 15.55 \\
\hline
\end{tabular}

*Significant at $5 \%$ level of probability error; DF = degrees of freedom; GY = grain yield; TGW = thousand grain weight; WH = weight of hectoliter; IGY = industrial grain yield.

Table 3. Mean values and parameters of adaptability and stability in oat cultivars with and without fungicide on grain yield and thousand grain weight.

\begin{tabular}{|c|c|c|c|c|c|c|c|c|}
\hline \multirow{3}{*}{ Genotype } & \multicolumn{4}{|c|}{ Without Fungicide } & \multicolumn{4}{|c|}{ With Fungicide } \\
\hline & $\beta_{0 i}$ & $\beta_{1 i}$ & $\delta_{i j}$ & $\mathrm{R}^{2}$ & $\beta_{0 i}$ & $\beta_{1 i}$ & $\delta_{\mathrm{ij}}$ & $\mathrm{R}^{2}$ \\
\hline & \multicolumn{8}{|c|}{ Grain yield $\left(\mathrm{kg} \cdot \mathrm{ha}^{-1}\right)$} \\
\hline Barbarasul & 2406 b & $0.71^{\text {ns }}$ & $-10256^{\mathrm{ns}}$ & 0.92 & $3053 \mathrm{~b}$ & $1.11^{\mathrm{ns}}$ & $-4336^{\mathrm{ns}}$ & 0.97 \\
\hline Brisasul & $2481 \mathrm{~b}$ & $0.96^{\text {ns }}$ & $148,973^{*}$ & 0.71 & 3529 a & $1.04^{\mathrm{ns}}$ & $60,575^{\mathrm{ns}}$ & 0.90 \\
\hline FAEM 4 Carlasul & 2666 a & $1.19^{\text {ns }}$ & $-12984^{\mathrm{ns}}$ & 0.98 & 3615 a & $0.85^{\mathrm{ns}}$ & $25,304^{\mathrm{ns}}$ & 0.91 \\
\hline FAEM 5 Chiarasul & 2683 a & $1.43^{*}$ & $280,632^{*}$ & 0.76 & $3141 \mathrm{~b}$ & $0.77^{\mathrm{ns}}$ & $-22,486^{\mathrm{ns}}$ & 0.98 \\
\hline IAC 7 & 1602 c & $1.01^{\mathrm{ns}}$ & $-17,652^{\mathrm{ns}}$ & 0.98 & $2375 d$ & $1.43^{*}$ & $18,294^{\mathrm{ns}}$ & 0.97 \\
\hline UPFA Gaudéria & $2568 \mathrm{~b}$ & $1.27^{\text {ns }}$ & $-28,927^{\text {ns }}$ & 0.99 & $3072 \mathrm{~b}$ & $1.05^{\mathrm{ns}}$ & $-31,017^{\mathrm{ns}}$ & 0.99 \\
\hline URS 21 & $2461 \mathrm{~b}$ & $1.13^{\mathrm{ns}}$ & $-9477^{\mathrm{ns}}$ & 0.97 & 2935 c & $0.65^{*}$ & $17,659^{\mathrm{ns}}$ & 0.87 \\
\hline
\end{tabular}




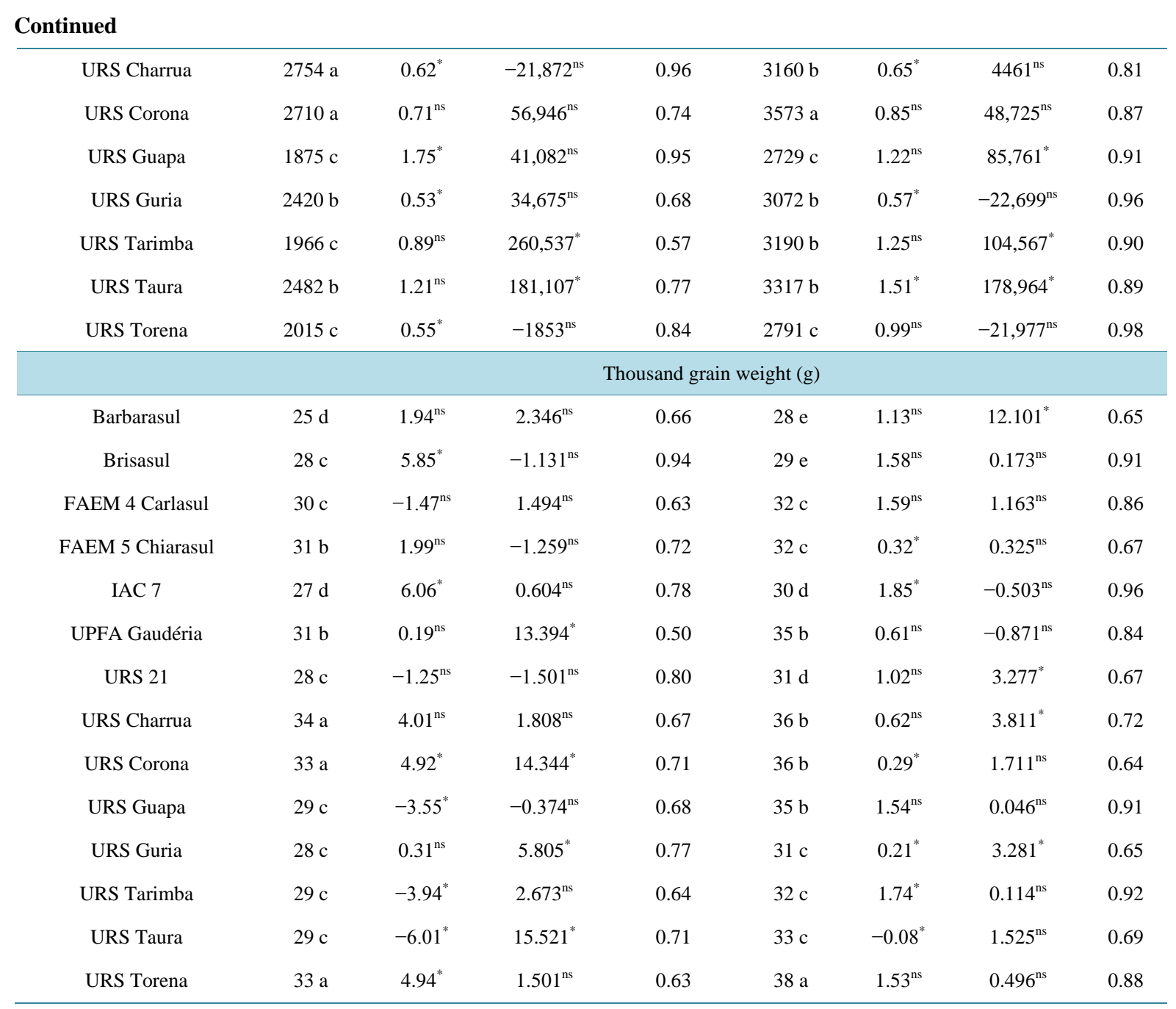

Means followed by the same letter do not differ significantly at $5 \%$ probability of error; ${ }^{*}=$ significant at $5 \%$ probability by $\mathrm{F}$ test; ${ }^{\mathrm{ns}}=$ not significant; $\beta_{0 i}=$ overall mean genotype $i ; \beta_{1 i}=$ Linear regression coefficient; $\delta_{i j}=$ regression deviations; $\mathrm{R}^{2}=$ coefficient of determination.

obtained by cultivars FAEM 4 Carlasul, FAEM 5 Chiarasul, URS Charrua and URS Corona. In these cultivars, in addition to high performance per se, was obtained general adaptability with stability in cultivars FAEM 4 Carlasul and URS Corona. Also stands out the genotype URS Charrua, which shows high means values with stability and adaptability to specific unfavorable environments $\left(\beta_{1 i}<1\right)$.

On application of fungicide (Table 3 ), the higher means values of grain yield were obtained by cultivars Brisasul, FAEM 4 Carlasul and URS Corona. These cultivars indicated also general adaptability with stability, characterized as qualified genotypes the recommendation in this scenario. Furthermore, the FAEM 4 Carlasul and URS Corona independent of use the fungicide, also presented high means with general adaptability and stability, standing out as ideal genotypes as recommended by the model. The model of [20] has been widely used in cereals, because, the adaptability and stability parameters by linear regression are more informative [6] [17] [21] [23]. Highlights that the grain yield due to the complex genetic control is usually the focus of the analysis of the interaction genotype versus environment [25] [26].

Reference [27] identified in oats favorable effect of greater stability of genotypes with the use of fungicide on the yield of grain. In this study, the use of fungicide is not increased the number of genotypes with stability, reinforcing the largest genetic stability of the current cultivars in different conditions of chemical control. Important to strengthen that studies with greater detail on the effects of the adaptability and stability in oats in the presence and absence of fungicide on the characters of industrial grain quality has not been found, highlighting the importance of this study about the research developed in this species. 
In Table 3, the greatest expression of the thousand grains weight in the environment without fungicide highlighted the cultivars URS Charrua, URS Corona and URS Torena. The URS Charrua is characterized as an ideal genotype, of high performance per se, broad adaptability and stability. The URS Corona and URS Torena they showed specific adaptability to favorable environment $\left(\beta_{1 i}>1\right)$, however, the URS Corona of unstable behavior differed from URS Torena which showed stability. In the analysis of the thousand grains weight in the presence of fungicide (Table 3), to cultivar URS Torena was the only that showed high mean value associated with the general adaptability and stability. Therefore, condition that qualifies as genotype higher expression of favorable alleles the grain filling in the presence of fungicide. On the other hand, the URS Corona even in group "b" highlighted specific adaptability the unfavorable environments with stability. Reference [28] highlights the importance of analyzing the thousand grain weight due to its high effect on the yield and quality of grain. In wheat, indirect effect and positive the thousand grain weight on the productivity of grain was also observed [22]. It is noteworthy that the thousand grains weight is a component linked to production in oats which shows the greatest damage by foliar diseases [9].

In weight of hectoliter (Table 4) most of the cultivars in the absence of fungicide showed high values with general adaptability. However, only cultivars FAEM 4 Carlasul, FAEM 5 Chiarasul, URS Charrua and URS

Table 4. Mean values and parameters of adaptability and stability in oat cultivars with and without fungicide on the weight of hectoliter and the industrial grain yield.

\begin{tabular}{|c|c|c|c|c|c|c|c|c|}
\hline \multirow{2}{*}{ Genotype } & \multicolumn{4}{|c|}{ Without Fungicide } & \multicolumn{4}{|c|}{ With Fungicide } \\
\hline & $\beta_{0 i}$ & $\beta_{1 i}$ & $\delta_{i j}$ & $\mathrm{R}^{2}$ & $\beta_{0 i}$ & $\beta_{1 i}$ & $\delta_{\mathrm{ij}}$ & $\mathrm{R}^{2}$ \\
\hline & \multicolumn{8}{|c|}{ Weight of hectoliter $\left(\mathrm{kg} \cdot \mathrm{hL}^{-1}\right)$} \\
\hline Barbarasul & $42 \mathrm{~b}$ & $0.92^{\mathrm{ns}}$ & $0.768^{\mathrm{ns}}$ & 0.95 & $46 \mathrm{~b}$ & $0.89^{\mathrm{ns}}$ & $-1.051^{\mathrm{ns}}$ & 0.97 \\
\hline Brisasul & $42 \mathrm{~b}$ & $0.79^{\mathrm{ns}}$ & $4.447^{*}$ & 0.85 & $46 \mathrm{~b}$ & $1.22^{\mathrm{ns}}$ & $1.215^{\mathrm{ns}}$ & 0.95 \\
\hline FAEM 4 Carlasul & $44 \mathrm{a}$ & $1.08^{\text {ns }}$ & $2.001^{\mathrm{ns}}$ & 0.95 & $47 \mathrm{~b}$ & $1.08^{\mathrm{ns}}$ & $5.006^{*}$ & 0.88 \\
\hline FAEM 5 Chiarasul & $45 \mathrm{a}$ & $0.92^{\text {ns }}$ & $2.379^{\mathrm{ns}}$ & 0.92 & $47 \mathrm{~b}$ & $0.87^{\mathrm{ns}}$ & $1.896^{\mathrm{ns}}$ & 0.89 \\
\hline IAC 7 & $43 \mathrm{a}$ & $0.84^{\mathrm{ns}}$ & $4.339^{*}$ & 0.87 & $47 \mathrm{~b}$ & $1.06^{\mathrm{ns}}$ & $4.612^{*}$ & 0.88 \\
\hline UPFA Gaudéria & $45 \mathrm{a}$ & $1.18^{\text {ns }}$ & $9.324^{*}$ & 0.87 & $48 \mathrm{a}$ & $0.93^{\mathrm{ns}}$ & $6.139^{*}$ & 0.82 \\
\hline URS 21 & $44 \mathrm{a}$ & $1.04^{\mathrm{ns}}$ & $4.099^{*}$ & 0.91 & $48 \mathrm{a}$ & $0.97^{\text {ns }}$ & $-0.966^{\text {ns }}$ & 0.97 \\
\hline URS Charrua & $45 \mathrm{a}$ & $0.91^{\mathrm{ns}}$ & $-1.253^{\mathrm{ns}}$ & 0.99 & $47 \mathrm{~b}$ & $0.99^{\mathrm{ns}}$ & $0.041^{\mathrm{ns}}$ & 0.95 \\
\hline URS Corona & $46 \mathrm{a}$ & $0.85^{\mathrm{ns}}$ & $7.781^{*}$ & 0.80 & $47 \mathrm{~b}$ & $0.85^{\mathrm{ns}}$ & $-0.063^{\mathrm{ns}}$ & 0.94 \\
\hline URS Guapa & 39 c & $1.34^{*}$ & $30.489^{*}$ & 0.74 & $45 \mathrm{~b}$ & $0.96^{\mathrm{ns}}$ & $3.281^{\mathrm{ns}}$ & 0.88 \\
\hline URS Guria & $44 \mathrm{a}$ & $0.96^{\mathrm{ns}}$ & $2.402^{\mathrm{ns}}$ & 0.93 & $48 \mathrm{a}$ & $1.14^{\mathrm{ns}}$ & $-1.916^{\mathrm{ns}}$ & 0.99 \\
\hline URS Tarimba & $43 \mathrm{~b}$ & $1.27^{*}$ & $3.981^{*}$ & 0.94 & 49 a & $0.89^{\mathrm{ns}}$ & $5.688^{*}$ & 0.81 \\
\hline URS Taura & $44 \mathrm{a}$ & $1.06^{\mathrm{ns}}$ & $10.662^{*}$ & 0.83 & $50 \mathrm{a}$ & $1.41^{*}$ & $-1.544^{\mathrm{ns}}$ & 0.99 \\
\hline \multirow[t]{2}{*}{ URS Torena } & $41 \mathrm{~b}$ & $0.77^{*}$ & $3.391^{*}$ & 0.87 & $46 \mathrm{~b}$ & $0.68^{*}$ & $0.852^{\mathrm{ns}}$ & 0.87 \\
\hline & \multicolumn{8}{|c|}{ Industrial grain yield $\left(\mathrm{kg} \cdot \mathrm{ha}^{-1}\right)$} \\
\hline Barbarasul & 689 c & $0.29^{*}$ & $47,220^{*}$ & 0.67 & $1246 \mathrm{c}$ & $0.66^{*}$ & $61,237^{*}$ & 0.72 \\
\hline Brisasul & 691 c & $0.16^{*}$ & $4667^{\text {ns }}$ & 0.69 & 1361 c & $1.41^{*}$ & $29,831^{\text {ns }}$ & 0.95 \\
\hline FAEM 4 Carlasul & 818 c & $1.01^{\mathrm{ns}}$ & $3245^{\text {ns }}$ & 0.91 & $1417 \mathrm{~b}$ & $0.75^{\mathrm{ns}}$ & $150,588^{*}$ & 0.64 \\
\hline FAEM 5 Chiarasul & 891 b & $1.26^{\mathrm{ns}}$ & $110,584^{*}$ & 0.64 & 1191 c & $0.91^{\mathrm{ns}}$ & $5941^{\mathrm{ns}}$ & 0.95 \\
\hline IAC 7 & $381 \mathrm{~d}$ & $0.72^{\mathrm{ns}}$ & $-2872^{\mathrm{ns}}$ & 0.91 & $729 \mathrm{~d}$ & $1.15^{\mathrm{ns}}$ & $29,499^{\text {ns }}$ & 0.93 \\
\hline UPFA Gaudéria & $986 \mathrm{~b}$ & $1.64^{*}$ & $39,116^{*}$ & 0.88 & $1522 \mathrm{~b}$ & $0.9^{\mathrm{ns}}$ & $-14,673^{\text {ns }}$ & 0.99 \\
\hline URS 21 & 685 c & $1.12^{\mathrm{ns}}$ & $-8799^{\mathrm{ns}}$ & 0.99 & 1139 c & $0.87^{\mathrm{ns}}$ & $-10,344^{\mathrm{ns}}$ & 0.99 \\
\hline URS Charrua & 1196 a & $1.27^{\mathrm{ns}}$ & $38,779^{*}$ & 0.82 & $1501 \mathrm{~b}$ & $0.62^{*}$ & $4917^{\text {ns }}$ & 0.90 \\
\hline URS Corona & 1125 a & $0.75^{\mathrm{ns}}$ & $79,926^{*}$ & 0.66 & $1822 \mathrm{a}$ & $1.04^{\mathrm{ns}}$ & $48,017^{*}$ & 0.88 \\
\hline URS Guapa & 813 c & $1.81^{*}$ & $8341^{\text {ns }}$ & 0.96 & 1299 c & $1.09^{\mathrm{ns}}$ & $51,618^{*}$ & 0.89 \\
\hline URS Guria & $694 \mathrm{c}$ & $0.66^{\mathrm{ns}}$ & $-8271^{\mathrm{ns}}$ & 0.98 & 1217 c & $0.86^{\mathrm{ns}}$ & $8011^{\mathrm{ns}}$ & 0.94 \\
\hline URS Tarimba & $660 \mathrm{c}$ & $0.94^{\mathrm{ns}}$ & $45,197^{*}$ & 0.68 & 1137 c & $1.02^{\mathrm{ns}}$ & $13,840^{\text {ns }}$ & 0.94 \\
\hline URS Taura & 1111 a & $1.86^{*}$ & $103,405^{*}$ & 0.80 & $1685 \mathrm{a}$ & $1.64^{*}$ & $1509^{\mathrm{ns}}$ & 0.99 \\
\hline URS Torena & $1004 \mathrm{~b}$ & $0.41^{*}$ & $30,287^{*}$ & 0.66 & 1654 a & $1.01^{*}$ & $26,396^{\text {ns }}$ & 0.91 \\
\hline
\end{tabular}

Means followed by the same letter do not differ significantly at $5 \%$ probability of error; ${ }^{*}=$ significant at $5 \%$ probability by $\mathrm{F}$ test; ${ }^{\mathrm{ns}}=$ not significant; $\beta_{0 i}=$ overall mean genotype $i ; \beta_{1 i}=$ Linear regression coefficient; $\delta_{i j}=$ regression deviations; $\mathrm{R}^{2}=$ coefficient of determination. 
Guria indicated stability. Provided with fungicide, the UPFA Gaudéria, URS 21, URS Guria, URS Tarimba and URS Taura highlighted values of greater magnitude. Among these, all with general adaptability, except the URS Taura that proved to be adjusted to favorable environments. It should be noted in this scenario, mean high in trait combined with general adaptability with stability obtained only by cultivar URS 21. Genetic and environmental differences are observed in the expression of the weight of hectolitre and grain. The grain weight by genotype and the weight of hectoliter by year of cultivation are the sources of variation that promote the biggest changes [22]. High temperatures increase the respiration rate and when combined with drought stress or excessive rainfall next the maturation, significantly reduce the weight of hectoliter [29] [30]. Furthermore, similar to the thousand grains weight, the weight of hectoliter in oats also shows the further damage by foliar diseases [9]. These damages are awarded by the reduction of area photosynthetic active and interference in translocation of photoassimilates from the leaves to the grains, consequently, lower deposition of reserves and reducing the commercial value of the final product [31].

In the industrial yield of grain (Table 4), the absence of fungicide excelled the cultivars URS Charrua, URS Corona and URS Taura the high performance per se. Both the URS Charrua as URS Corona showed general adaptability and the URS Taura, specific adaptability the favorable environments, although, none have shown stability. The genotype FAEM 4 Carlasul in the third group of performance ("c") indicated general adaptability with stability. Provided with fungicide (Table 4), all genotypes tested showed industrial output exceeding 1 $\mathrm{t} \cdot \mathrm{ha}^{-1}$, except to cultivar IAC 7. In this condition, the cultivars URS Corona, URS Taura and URS Torena obtained the most expressive values. Among these, the URS Torena showed high means values with general adaptability and stability. And even the URS Corona having evidenced expression instability, counts with ample adaptability, opposite of URS Taura, of stability and adaptability specifies the favorable environments.

In a globalized market achieve self-sufficiency and competitiveness of Brazilian oat is decisive. Soon, climate change on the planet have provided a new challenge in global agricultural production, as well as obtaining more productive cultivars, they are more resistant to disease and tolerant to environmental stresses, require greater adaptation and stability in agricultural crops [32]. However, the growing demand for higher quality oats industry processing and more nutritious and healthy consumption has been increasingly required [6], justifying the need for reduction in the use of agrochemicals to control foliar diseases [15]. The results of this research show the importance of understanding the effects the unfolding of the interaction genotype versus environment on yield and industrial quality of oat grains in the absence and presence of fungicide, highlighting this determination about the new elite genotypes for commercial launch and optimize the recommendation of cultivars for producers of oats in Brazil.

\section{Conclusions}

The white oat cultivars FAEM 4 Carlasul and URS Corona indicate high grain yield with stability and general adaptability, independent of chemical control.

The cultivar URS Charrua together shows high yield and thousand grain weight and weight of hectoliter with general adaptability and stability in the absence of fungicide.

Although no stability has been detected in industrial yield without the use of fungicides, cultivars URS Charrua, URS Corona and URS Taura show high means with general adaptability.

\section{Acknowledgements}

To CNPq, CAPES, FAPERGS and UNIJUí by the contribution of resources for the development of this research and by grants for Scientific and Technological Initiation and Research Productivity.

\section{References}

[1] Floss, E.L., Palhano, A.L., Filho, C.V.S. and Premazzi, L.M. (2007) Crescimento, produtividade, caracterização e composição química da aveia branca. Acta Scientiarum Animal Science, 29, 1-7. http://dx.doi.org/10.4025/actascianimsci.v29i1.241

[2] Silva, J.A.G., Fontaniva, C., Costa, J.S.P., Krüger, C.A.M.B., Ubessi, C., Pinto, F.B., Arenhardt, E.G. and Gewehr, E. (2012) Uma proposta na densidade de semeadura de um biotipo atual de cultivares de aveia. Revista Brasileira de Agrociência, 18, 253-263.

[3] Hartwig, I., Silva, J.A.G., Carvalho, F.I.F., Oliveira, A.C., Bertan, I., Valério, I.P., Silva, G.O., Ribeiro, G., Finatto, T. 
and Silveira, G. (2007) Variabilidade fenotípica de caracteres adaptativos da aveia branca (Avena sativa L.) em cruzamentos dialélicos. Ciência Rural, 37, 337-345. http://dx.doi.org/10.1590/S0103-84782007000200007

[4] Gutkoski, L.C., Bonamigo, J.M.A., Teixeira, D.M.F. and Pedó, I. (2007) Desenvolvimento de barras de cereais à base de aveia com alto teor de fibra alimentar. Ciência e Tecnologia de Alimentos, 27, 355-363. http://dx.doi.org/10.1590/S0101-20612007000200025

[5] Hawerroth, M.C., Carvalho, F.I.F., Oliveira, A.C., Silva, J.A.G., Gutkoski, L.C., Sartori, J.F., Woyann, L.G., Barbieri, R.L. and Hawerroth, F.J. (2013) Adaptability and Stability of White Oatcultivars as to Chemical Composition of the Caryopsis. Pesquisa Agropecuária Brasileira, 48, 42-50. http://dx.doi.org/10.1590/S0100-204X2013000100006

[6] Crestani, M., Carvalho, F.I.F., Oliveira, A.C., Silva, J.A.G., Gutkoski, L.C., Sartori, J.F., Barbieri, R.L. and Baretta, D. (2010) Conteúdo de $\beta$-glucana em cultivares de aveia-branca cultivadas em diferentes ambientes. Pesquisa Agropecuária Brasileira, 45, 261-268.

[7] Klajn, V.M., Colussi, R., Fiorentini, A.M., Elias, M.C. and Gutkoski, L.C. (2014) Processamento hidrotérmico em escala industrial sobre parâmetros de qualidade em frações de aveia. Ciência Rural, 44, 931-936. http://dx.doi.org/10.1590/S0103-84782014000500027

[8] Alves, A.C. and Kist, T.V. (2010) Composição da espigueta de aveia branca (Avena sativa L.). Revista Brasileira de Agrociência, 16, 29-33.

[9] Nerbass Júnior, J.M., Casa, R.T., Gava, F., Bogo, A., Kuhnem Junior, P.R. and Bolzan, J.M. (2008) Controle de doenças foliares na aveia branca e danos na produção em resposta à dose e ao número de aplicações de fungicida. Revista de Ciências Agroveterinárias, 7, 127-134.

[10] Leite, J.G.D.B., Federizzi, L.C. and Bergamaschi, H. (2012) Mudanças climáticas e seus possíveis impactos aos sistemas agrícolas no Sul do Brasil. Revista Brasileira de Ciências Agrárias, 7, 337-343. http://dx.doi.org/10.5039/agraria.v7i2a1239

[11] Vieira, E.A., Carvalho, F.I.F., Chaves, M.S., Oliveira, A.C., Bertan, I., Martins, A.F., Hartwig, I., Benin, G., Valério, I. and Fonseca, D.A.R. (2006) Padrão de resistência de genótipos de aveia à ferrugem-da-folha na definição de hibridações. Pesquisa Agropecuária Brasileira, 41, 607-614. http://dx.doi.org/10.1590/S0100-204X2006000400009

[12] Nerbass Júnior, J.M., Casa, R.T., Kuhnem Junior, P.R., Gava, F. and Bogo, A. (2010) Modelos de pontos críticos para relacionar o rendimento de grãos de aveia branca com a intensidade de doença no patossistema múltiplo ferrugem da folha:helmintosporiose. Ciência Rural, 40, 1-6. http://dx.doi.org/10.1590/S0103-84782009005000228

[13] Kuhnem Junior, P.R., Casa, R.T., Rizzi, F.P., Moreira, E.M. and Bogo, A. (2009) Desempenho de fungicidas no controle de doenças foliares em trigo. Revista de Ciências Agroveterinárias, 8, 35-42.

[14] Tormen, N.R., Lenz, G., Minuzzi, S.G., Uebel, J.D., Cezar, H.S. and Balardin, R.S. (2013) Reação de cultivares de trigo à ferrugem da folha e mancha amarela e responsividade a fungicidas. Ciência Rural, 43, 239-246. http://dx.doi.org/10.1590/S0103-84782013000200008

[15] Santos, J.O., Santos, R.M.S., Fernandes, A.A., Souso, J.S., Borges, M.G.B., Ferreira, R.T.F.V. and Salgado, A.B. (2013) Os impactos produzidos pelas mudanças climáticas. AgropecuáriaCientífica no Semiárido, 9, 9-16.

[16] Agostinetto, L., Casa, R.T., Bogo, A., Sachs, C., Reis, E.M. and Kuhnem, P.R. (2014) Critical Yield-Point Model to Estimate Damage Caused by Brown Spot and Powdery Mildew in Barley. Ciência Rural, 44, 957-963. http://dx.doi.org/10.1590/S0103-84782014000600001

[17] Storck, L., Cargnelutti Filho, A. and Guadagnin, J.P. (2014) Análise conjunta de ensaios de cultivares de milho por classes de interação genótipo $\times$ ambiente. Pesquisa Agropecuária Brasileira, 49, 163-172. http://dx.doi.org/10.1590/S0100-204X2014000300002

[18] Oliveira, D.M., Souza, A.M., Rocha, V.S. and Assis, J.C. (2011) Desempenho de genitores e populações segregantes de trigo sob estresse de calor. Bragantia, 70, 25-32. http://dx.doi.org/10.1590/S0006-87052011000100005

[19] Scott, A.J. and Knott, M.A. (1974) A Cluster Analysis Method for Grouping Means in the Analysis of Variance. Biometrics, 30, 507-512. http://dx.doi.org/10.2307/2529204

[20] Eberhart, S.A. and Russell, W.A. (1966) Stability Parameters for Comparing Varieties. Crop Science, 6, 36-40. http://dx.doi.org/10.2135/cropsci1966.0011183X000600010011x

[21] Federizzi, L.C., Neto, J.F.B., Carvalho, F.I.F., Viau, L.V.M., Severo, J.L., Floss, E.L., Alves, A., Almeida, J. and Silva, A.C. (1993) Estabilidade no rendimento de grãos em aveia: Efeito do uso de fungicidas. Pesquisa Agropecuária Brasileira, 28, 465-472.

[22] Benin, G., Carvalho, F.I.F., Oliveira, A.C., Lorencetti, C., Vieira, E.A., Coimbra, J.L.M., Valério, I.P., Floss, E.L., Bertan, I. and Silva, G.O. (2005) Adaptabilidade e estabilidade em aveia em ambientes estratificados. Ciência Rural, 35, 295-302. http://dx.doi.org/10.1590/S0103-84782005000200008

[23] Luche, H.S., Nornberg, R., Crestani, M., Ribeiro, G., Woyann, L.G., Silva, J.A.G., Maia, L.C. and Oliveira, A.C. (2013) 
Parâmetros de adaptabilidade e estabilidade em cultivares brasileiras e estrangeiras de aveia branca. Current Agricultural Science and Technology, 19, 31-40.

[24] Vasconcelos, E.S., Reis, M.S., Cruz, C.D., Sediyama, T. and Scapim, C.A. (2010) Adaptability and Stability of Semilate and Late Maturing Soybean Genotypes in Minas Gerais State. Acta Scientiarum Agronomy, 32, 411-415. http://dx.doi.org/10.4025/actasciagron.v32i3.8249

[25] Alvarenga, C.B., Sobrinho, J.S. and Alvarenga, P.B. (2009) Comportamento de genótipos de trigo cultivados no Cerrado do Brasil Central, em diferentes municípios do estado de Minas Gerais. Bioscience Journal, 25, 93-97.

[26] Condé, A.B.T., Coelho, M.A.O., Yamanaka, C.H. and Corte, H.R. (2010) Adaptabilidade e estabilidade de genótipos de trigo sob cultivo de sequeiro em Minas Gerais. Pesquisa Agropecuária Tropical, 40, 45-52.

[27] Lorencetti, C., Carvalho, F.I.F., Marchioro, V.S., Benin, G., Oliveira, A.C. and Floss, E.L. (2004) Implicações da aplicação de fungicida na adaptabilidade e estabilidade de rendimento de grãos em aveia branca. Ciência Rural, 34, 693-700. http://dx.doi.org/10.1590/S0103-84782004000300007

[28] Vesohoski, F., Marchioro, V.S., Franco, F.A. and Contelle, A. (2011) Componentes do rendimento de grãos em trigo e seus efeitos diretos e indiretos na produtividade. Revista Ceres, 58, 337-341. http://dx.doi.org/10.1590/S0034-737X2011000300014

[29] Bhatt, G.M., Paulsen, G.M., Kulp, K. and Heyne, E.G. (1981) Preharvest Sprouting in Hard Winter Wheats: Assessment of Methods to Detect Genotypic and Nitrogen Effects and Interactions. Cereal Chemistry, 58, 300-302.

[30] Prasad, P.V.V., Pisipati, S.R., Momcilovic, I. and Ristic, Z. (2011) Independent and Combined Effects of High Temperature and Drought Stress during Grain Filling on Plant Yield and Chloroplast EF-Tu Expression in Spring Wheat. Journal of Agronomy and Crop Science, 197, 430-441. http://dx.doi.org/10.1111/j.1439-037X.2011.00477.X

[31] Bohatchuk, D.A., Casa, R.T., Bogo, A., Kuhnem Junior, P.R., Reis, E.M. and Moreira, E.M. (2008) Modelo de ponto crítico para estimar danos de doenças foliares do trigo em patossistema múltiplo. Tropical Plant Pathology, 33, 363369. http://dx.doi.org/10.1590/S1982-56762008000500004

[32] Araus, J.L., Slafer, G.A., Royo, C. and Serret, M.D. (2008) Breeding for Yield Potential and Stress Adaptation in Cereals. Critical Reviews in Plant Science, 27, 377-412. http://dx.doi.org/10.1080/07352680802467736 